\title{
20. RATES OF SEDIMENT ACCUMULATION AT DEEP SEA DRILLING PROJECT LEG 65 SITES AT THE MOUTH OF THE GULF OF CALIFORNIA ${ }^{1}$
}

\author{
Richard N. Benson, Delaware Geological Survey, University of Delaware, Newark, Delaware
}

\section{INTRODUCTION}

The hemipelagic silty clays and silty fine-grained sands overlying basement at Deep Sea Drilling Project (DSDP) Leg 65 sites at the mouth of the Gulf of California are no older than Quaternary in age (see site chapters, this volume). The sediments are predominantly of terrigenous origin, derived from the adjacent continental landmasses of mainland Mexico and the peninsula of Baja California. Pelagic biogenic components, averaged for each site from estimates of their areal abundances on smear slides of core samples, range from only about $15 \%$ at Site 482 to about $30 \%$ at Site 484 . Rates of sediment accumulation are high. Averaged minimum rates range from $7.1 \mathrm{~cm} / 1000 \mathrm{y}$. at Site 483 to $33.4 \mathrm{~cm} / 1000$ y. at Site 482 (Fig. 1).

Submarine topography and bottom currents (turbidity currents and, probably, contour currents) are the primary controls of the distribution of sediments overlying and interlayered with the young basaltic crust at the mouth of the Gulf. Sediments are concentrated in longitudinal valleys separated by ridges parallel to the axis of the East Pacific Rise and in the valley associated with the Tamayo Fracture Zone (Lewis, 1979; Glomar Challenger seismic reflection profiles, this volume).

\section{DISTRIBUTION OF SEDIMENTS}

The sediment-filled longitudinal valleys and parallel ridges are distributed symmetrically on either side of the axis of the East Pacific Rise (Figs. 1 and 2). Lewis (1979) hypothesized that both the ridges and valleys formed at the axis of the Rise but at different times, the periodicity of their formation being related to periodicities in magma supply rate. The ridges, comprised of pillow basalts, and characterized by rough topography, represent ancient axial highs that were formed by constructional processes when magma supply was abundant. The valleys represent ancient axial valleys that formed as a result of rifting unaccompanied by large volumes of basalt. Massive rather than pillowed basalt flows were characteristic of these latter times and were ponded in the valleys, producing a smooth basement surface. Sediments were interlayered with flows or possibly intruded by sills. When volcanic contributions ceased, only the sediments accumulated above the smooth basement.

Seismic reflection profiles crossing the valleys and ridges at right angles clearly reveal the distribution of

\footnotetext{
'Lewis, B. T. R., Robinson, P., et al., Init. Repts. DSDP, 65: Washington (U.S. Govt. Printing Office).
}

sediments (Lewis, 1979; Lewis et al., this volume; IPOD site survey of 1975). Figure 2 shows the greater thickness of sediment nearly filling the longitudinal valleys on the southeastern side of the axis of the East Pacific Rise compared to the thinner sedimentary accumulations in valleys on the northwestern side. This reflects the nearness of the source area of mainland Mexico to the southeastern valleys. Sediment accumulation rates are higher at Sites 482 and 485 (southeastern valleys) than at sites to the northwest (Fig. 1). Also, the average percentage of pelagic biogenic components is higher at the northwestern sites $(23 \%$ at Site $483,32 \%$ at Site 484$)$ than at the southeastern sites $(14 \%$ at Site $482,21 \%$ at Site 485).

Although the sediments at all sites are predominantly silty clay, there are many coarser-grained units interpreted as fine-grained turbidites because they show fining-upward sequences and contain abundant quartz and feldspar grains of continental origin and reworked foraminifers. Even the silty clays may have been deposited, either originally or by redeposition, as fine-grained turbidites or perhaps by contour currents. This is suggested by the absence or near absence of sediments on the ridges and their concentration in valleys. Also, as shown on the seismic reflection profiles for the valleys on either side of the axis of the East Pacific Rise, neither the internal layering of the sediments nor the sediment-water interface is completely horizontal but rise against the ridges in directions toward the axis of the Rise (Fig. 2; Lewis, 1979; Lewis et al., this volume; IPOD site survey of 1975). This may be the result of molding of sediments by contour currents oriented along the axes of the longitudinal valleys.

\section{RATES OF SEDIMENT ACCUMULATION}

Both radiolarians (see Benson, this volume) and calcareous nannofossils (see Hattner, this volume) provide reliable datum levels for the calculation of rates of sediment accumulation at Leg 65 sites. From youngest to oldest they are: (1) the highest occurrence of the radiolarian Axoprunum angelinum ( $=$ Stylatractus universus) at $0.41 \pm 0.005 \mathrm{Ma}$ (Hays and Shackleton, 1976); (2) the boundary between the Gephyrocapsa oceanica and Pseudoemiliana lacunosa calcareous nannofossil zones at $0.44 \mathrm{Ma}$ (Gartner, 1977); and (3) the highest occurrence of the coccolith Cyclococcolithina macintyrei at $1.51 \mathrm{Ma}$ (Gartner, 1977). At Site 483 calcareous nannofossils of Pliocene age were recovered from within the basalt-sediment sequence below the top of the basement. They are representative of the late Pliocene Zone 


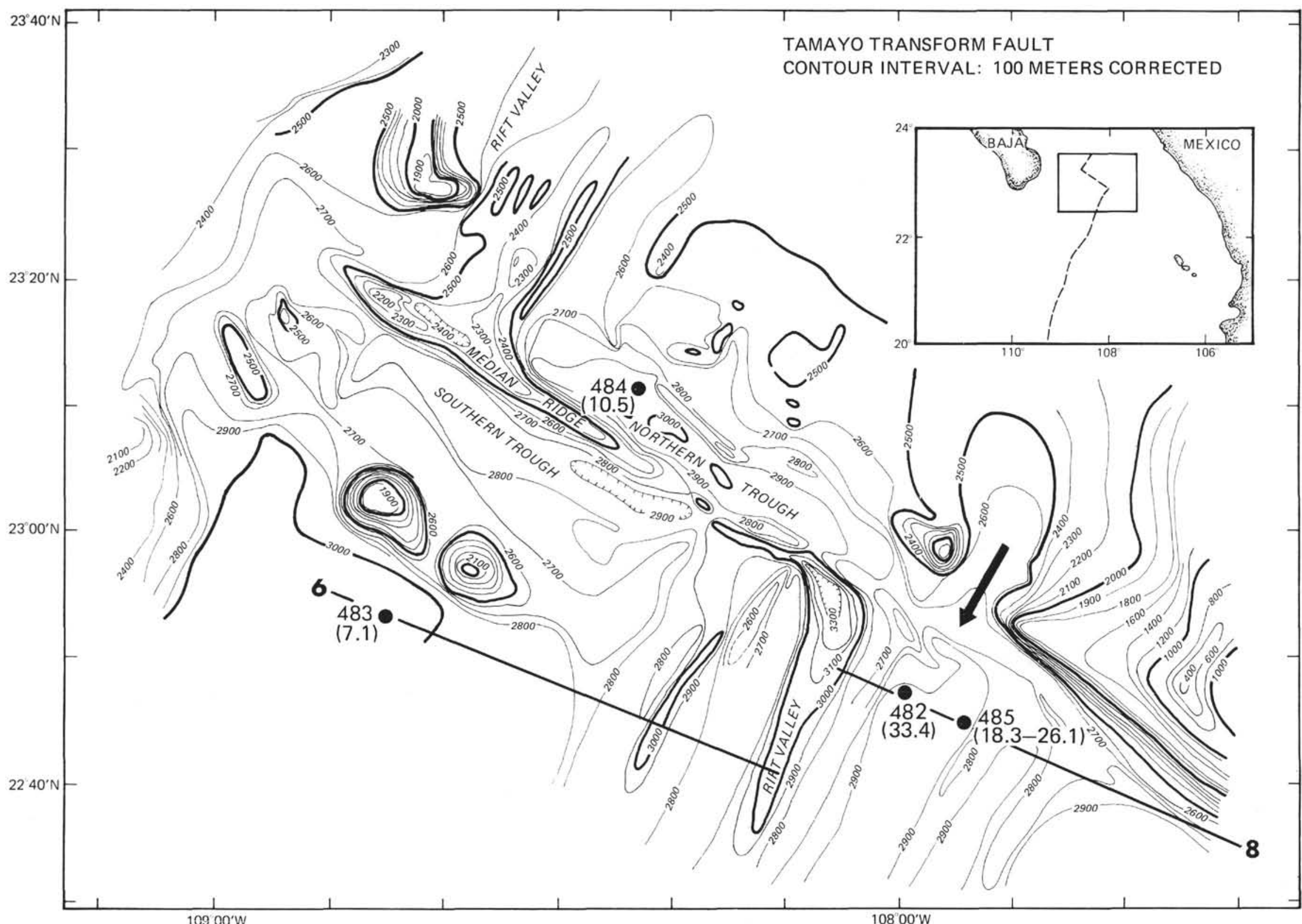

Figure 1. Location map at the mouth of the Gulf of California. Averaged minimum rates of accumulation of sediments overlying basement in $\mathrm{cm} / 1000 \mathrm{y}$. are indicated in parentheses for each Leg 65 site. Arrow in submarine canyon indicates direction and probable major locus of presumed turbidity currents that transported terrigenous sediment to the longitudinal valleys southeast of the axis of the East Pacific Rise. Lines 6 and 8 show locations of seismic reflection profiles 6 and 8 shown in Figure 2 . 


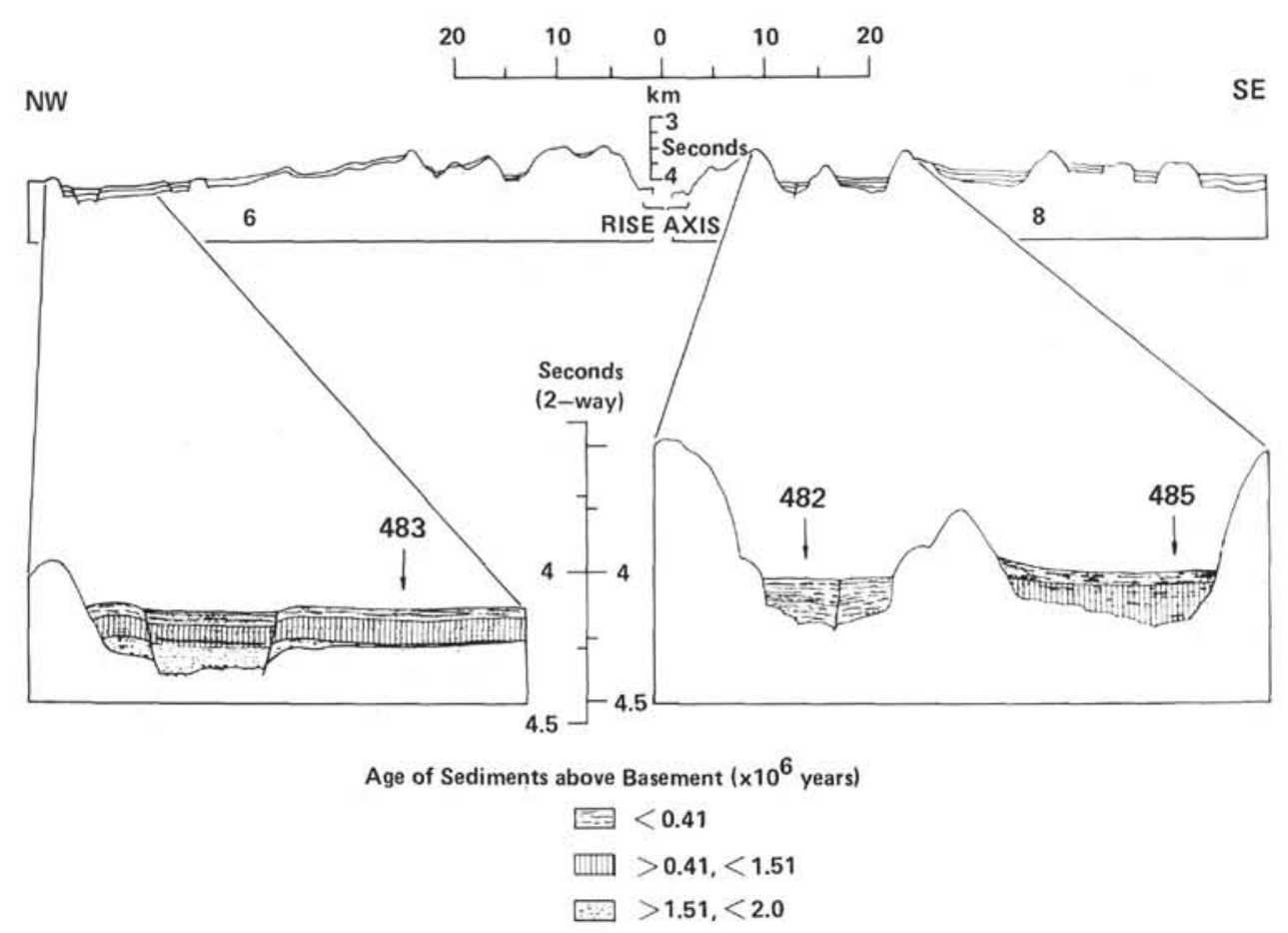

Figure 2. Interpretations of portions of site survey seismic reflection profiles 6 and 8 (site survey chapter, this volume), illustrating the distribution and age of sediments in longitudinal valleys parallel to the axis of the East Pacific Rise).

NN18, Discoaster brouweri, but are generally poorly preserved (Hattner, this volume). The extinction of $D$. brouweri is dated at $1.65 \mathrm{Ma}$ (Gartner, 1977).

With one exception, sediment accumulation rates were calculated for only those sediments overlying basement because of uncertainties in estimating the total thickness of sediment interlayered with basalt beneath the basement surface. The first two datum levels indicated above are of nearly the same age ( 0.41 and 0.44 $\mathrm{Ma}$ ) and were identified at three of the four sites at similar depths; therefore, only one, the younger radiolarian datum of $0.41 \mathrm{Ma}$, was used in the calculations.

Figure 2 illustrates the thickness and age of sediments above basement at the three drilling sites located in the longitudinal valleys. The time-stratigraphic boundaries within the sediment pile of each valley coincide with seismic reflectors at the datum levels of 0.41 and 1.51 $\mathrm{Ma}$, where identified at each site. Although the sediment older than 1.51 m.y. at Site 483 is younger than $1.65 \mathrm{~m} . \mathrm{y}$. (at least above basement), the older sediments in the graben to the northwest may be older than 1.65 m.y. but are probably younger than 2.0 m.y.

The calculated rates of sediment accumulation at all four Leg 65 sites are given in Table 1. Extrapolated ages of sediment at the contact with basement were used for determining the averaged minimum rate for all sediments above basement. Because neither $A$. angelinum nor $P$. lacunosa was found at Site 482 , the entire sedimentary section (including sediments interlayered with basalt) in the first longitudinal valley to the southeast of the axis of the East Pacific Rise is younger than 0.41 m.y. For Site 483, an age of 1.56 m.y. was calculated, assuming the sediment accumulation rate between 106 and 110 meters sub-bottom was $6.5 \mathrm{~cm} / 1000 \mathrm{y}$. For Site 484 , the rate of $10.5 \mathrm{~cm} / 1000 \mathrm{y}$. obtained for the upper 43 meters was assumed for the entire 62 meters of sediment overlying basement, giving an estimated age of 0.59 m.y. for the base of the sediment pile.

The age at the base of the sedimentary section overlying basement at Site 485 is subject to a greater degree of uncertainty. In this case, extrapolated ages were based in part on the thickness of sediments drilled within the basalts. As determined from geophysical logs, this amounts to 100 meters. Using calcareous nannofossils, Hattner (this volume) determined that the lowest of the cored sedimentary units interbedded with basalt is younger than $1.2 \mathrm{~m}$.y. Using this figure as a maximum age, the minimum rate of sediment accumulation for the 219 meters of sediment drilled between 35 meters sub-bottom and the bottom of the hole is $27.7 \mathrm{~cm} / 1000 \mathrm{y}$. The extrapolated age of the base of the sediment pile overlying basement at 154 meters is $0.84 \mathrm{~m} . \mathrm{y}$. Another approach to determining this age is based on interpretation of the magnetic anomaly pattern. Site 485 lies approximately in the middle of a reversed anomaly which B. Lewis (personal communication) interprets as that portion of the Matuyama reversed anomaly lying between the Brunhes and Jaramillo normal events, i.e., in the middle of a time interval extending from 0.89 to $0.7 \mathrm{Ma}$. This gives a maximum crustal age at Site 485 of about 0.8 m.y. Using this figure, the rate of sediment accumulation for the 219 meters of sediment drilled between 35 meters sub-bottom and the bottom of the hole, plus an estimated 35 meters of undrilled sediment below this (P. Robinson, personal communication), a total of 254 meters, is $65.1 \mathrm{~cm} / 1000 \mathrm{y}$. Using this rate, the extrapolated 
Table 1. Rates of sediment accumulation at Leg 65 sites.

\begin{tabular}{|c|c|c|c|c|c|c|c|}
\hline \multirow[b]{3}{*}{ Site } & \multicolumn{3}{|c|}{ Sub-bottom Depth (m) } & \multirow{3}{*}{$\begin{array}{l}\text { Extrapolated Age } \\
\text { of Sediment at } \\
\text { Basement (Ma) }\end{array}$} & \multicolumn{3}{|c|}{ Rates of Sediment Accumulation $(\mathrm{cm} / 1000 \mathrm{y})}$. \\
\hline & \multicolumn{2}{|c|}{ To Datum Levels } & \multirow{2}{*}{$\begin{array}{c}\text { To } \\
\text { Basement }\end{array}$} & & \multirow[b]{2}{*}{$<0.41 \mathrm{Ma}$} & \multirow[b]{2}{*}{$>0.41 \mathrm{Ma}$} & \multirow{2}{*}{$\begin{array}{l}\text { Averaged Minimum } \\
\text { Rate for Sediment } \\
\text { Overlying Basement }\end{array}$} \\
\hline & $0.41 \mathrm{Ma}$ & $1.51 \mathrm{Ma}$ & & & & & \\
\hline 482 & - & - & 137 & $<0.41$ & $>33.4$ & - & 33.4 \\
\hline 483 & 34 & 106 & 110 & 1.56 & 8.3 & 6.5 & 7.1 \\
\hline 484 & 43 & - & 62 & 0.59 & 10.5 & 10.5 & 10.5 \\
\hline 485 & 35 & - & 154 & $0.59-0.84$ & 8.5 & $27.7-65.1$ & $18.3-26.1$ \\
\hline
\end{tabular}

age of the sediment at the top of the basement is 0.59 m.y.

\section{DISCUSSION}

There is ample evidence from all four Leg 65 sites that sandy turbidites are present. The high rates of sediment accumulation also suggest that the bulk of the sediments, olive gray silty clays, are of terrigenous origin and were deposited by bottom currents-turbidity currents and/or contour currents. For Sites 483 and 484 the locus of these currents is unknown. However, the mouth of a submarine valley adjacent to the foot of a continental block detached from mainland Mexico lies opposite the longitudinal valleys in which Sites 482 and 485 are located, and the axis of the valley is parallel to the axes of the longitudinal valleys (Fig 1). I suggest that this submarine valley was, and probably still is, the major locus of sediment transport to the longitudinal valleys southeast of the axis of the East Pacific Rise.

The evidence on the age of the sediment above basement at Sites 482 and 485 (Fig. 2) suggests that as new seafloor formed and moved southeastward from the spreading center at the axis of the East Pacific Rise, the open ends of the longitudinal valleys on the southwestern side of the Tamayo Fracture Zone moved past the mouth of the submarine valley. If transportation of terrigenous sediment down the axis of the valley was more or less constant during the Quaternary, sedimentation in each of the longitudinal valleys was rapid at first and then tapered off as the open end of the longitudinal valley moved away from the mouth of the submarine valley northeast of the Tamayo Fracture Zone. At Site 485 , the early sediment accumulation rate was high $(27.7-65.1 \mathrm{~cm} / 1000 \mathrm{y}$.) whereas the later sediments (the upper $35 \mathrm{~m}$ ) accumulated at the much slower rate of 8.5 $\mathrm{cm} / 1000 \mathrm{y}$. when the longitudinal valley of Site 482 was (and still is) opposite the mouth of the submarine valley and receiving sediment at a rate in excess of $33.4 \mathrm{~cm} /$ $1000 \mathrm{y}$.

Figure 3 shows paleobathymetric reconstructions that test this hypothesis. The extrapolated ages of sediment at basement for Figures $3 \mathrm{~A}-\mathrm{C}$ are from Table 1. The figure is based on the following assumptions: (1) a halfspreading rate of $2.9 \mathrm{~cm} / \mathrm{y}$. for the East Pacific Rise near $23^{\circ} \mathrm{N}$ (Lewis, 1979); (2) the block northeast of the Tamayo Fracture Zone remained stationary with respect to the spreading axis to the southwest, i.e., the two blocks were decoupled and sinistral relative displacement occurred across the fracture zone; (3) the submarine valley on the northeast existed in its present form throughout the Quaternary and was a continuing major supplier of sediment to the longitudinal valleys.

Some or all of these assumptions may not be entirely correct because when Site 485 was receiving sediment at the higher rate of $27.7-65.1 \mathrm{~cm} / 1000 \mathrm{y}$., the open end of the longitudinal valley in which it is located was not directly opposite the mouth of the submarine valley to the northeast (Figs. 3A-C). The present location of Site 482 opposite the mouth of the submarine valley (Figure 3D) offers better support of the hypothesis that the valley is a major locus of sediment transport.

Different assumptions could explain the discrepancy provided by the data for Site 485 . First, a more rapid half-spreading rate during the time interval between 0.84 and $0.41 \mathrm{Ma}$, e.g., 4- $6 \mathrm{~cm} / \mathrm{y}$., would bring Site 485 opposite the submarine valley during times of maximum rate of sediment accumulation. Second, the submarine valley on the northeast may not be or have been the only locus of major sediment supply to the longitudinal valleys. Third, terrigenous sediment supply may have been episodic, greater during times of lowered sea level when continental glaciation was at a maximum. Rapid sedimentation of all the longitudinal valleys could have occurred even if they were not directly opposite the submarine valley on the northeast (Figs. 3B-C).

A final alternate assumption to account for the high rate of sedimentation in the valley occupied by Site 485 during the time represented by Figures $3 \mathrm{~A}-\mathrm{C}$ is twofold: (1) when the valley of Site 485 was the ancient axial valley of the East Pacific Rise, it was opposite the mouth of the submarine valley to the northeast, and (2) there was no differential movement between the two crustal blocks on either side of the Tamayo Fracture Zone until after most of the sediment had accumulated at Site 485 , i.e., decoupling of the blocks did not occur until sometime shortly before $0.41 \mathrm{Ma}$ (Fig. 3C), after which time the valley of Site 482 moved opposite the mouth of the submarine valley on the northeast. If this were true it would imply that at present there is sinistral relative displacement along the Tamayo Fracture Zone southeast of its intersection with the axis of the East Pacific Rise (transcurrent faulting beyond the end of a transform fault), whereas prior to about $0.41 \mathrm{Ma}$ there was no relative displacement (a true transform fault in which there is no relative displacement of crustal blocks beyond its ends).

\section{CONCLUSIONS}

That rates of sediment accumulation at the mouth of the Gulf of California are high is not suprising because of the proximity of the continental landmasses of mainland Mexico and the peninsula of Baja California. The 


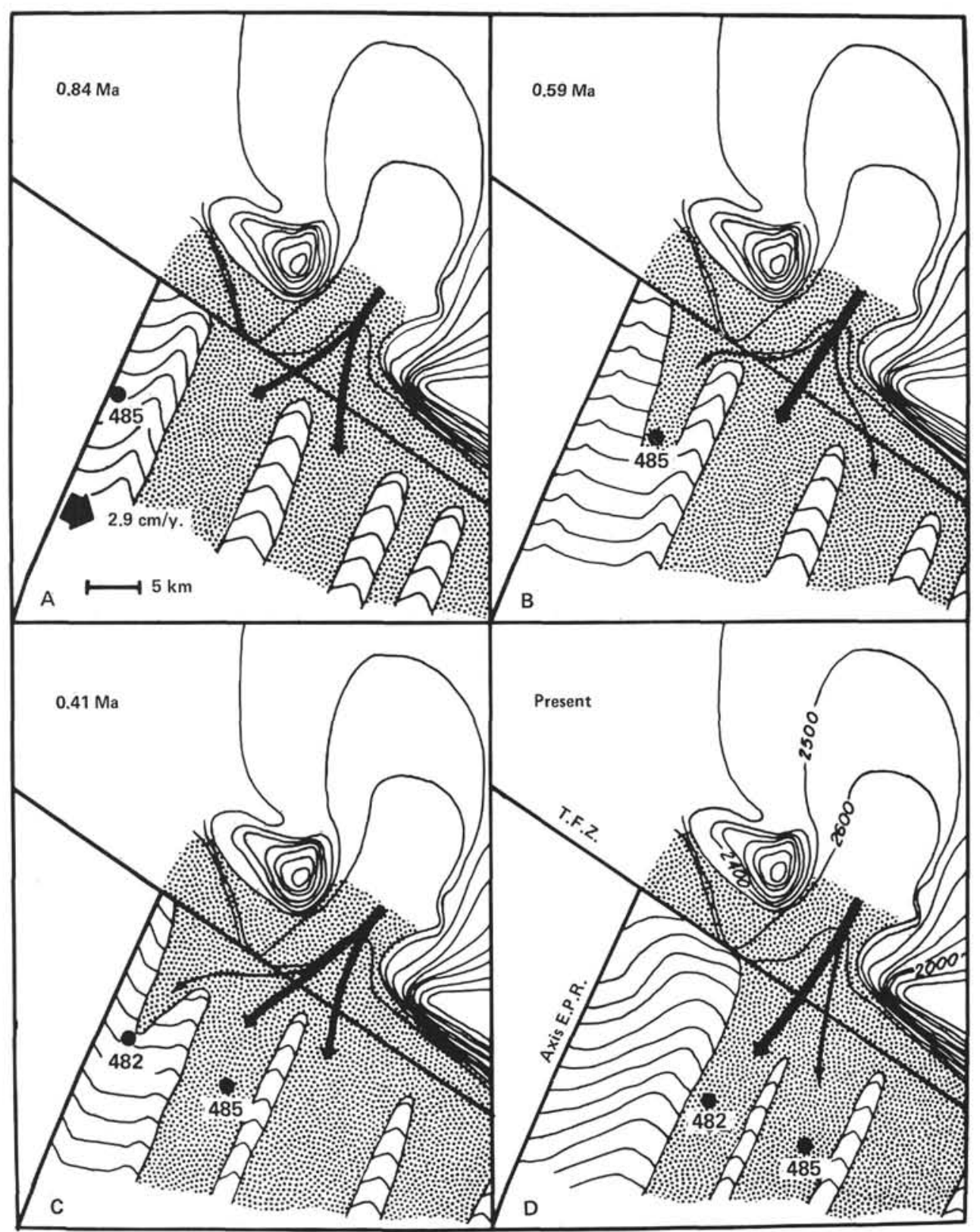

Figure 3. Postulated sequential filling of longitudinal valleys southeast of the axis of the East Pacific Rise by turbidites derived from mainland Mexico. Arrows indicate direction of sediment transport. Width of arrows proportional to amount of sediment transported. (Contour interval northeast of Tamayo Fracture Zone: 100 meters. T.F.Z. = Tamayo Fracture Zone. E.P.R. = East Pacific Rise) .

biostratigraphic information derived from DSDP Leg 65 sediment cores provides a good control on the age of sediments both above basement and interlayered with the basalts. On the basis of this information and that provided by seismic reflection profiles I draw the following conclusions:

1) The sediments at the mouth of the Gulf of California are primarily of terrigenous origin. Pelagic biogenic components averaged for each site range from about $15 \%$ to $30 \%$, being higher the farther the site is from land.
2) Submarine topography and bottom currents (turbidity and/or contour currents) control the distribution of sediments. The sediments are concentrated in longitudinal valleys parallel to the axis of the East Pacific Rise and are absent from the ridges.

3) Rates of sediment accumulation are two to three times higher at Sites 482 and 485 than at Sites 483 and 484. Sites 482 and 485 are adjacent to major sources of terrigenous sediment-a submerged continental block detached from mainland Mexico and a submarine valley that was probably the locus of turbidity currents which 
rapidly deposited sediment in the longitudinal valleys in which Sites 482 and 485 are located.

4) Circumstantial evidence suggests that the longitudinal valleys of Sites 482 and 485 moved in conveyorbelt fashion past the mouth of the submarine valley. Sediment filled the longitudinal valleys rapidly and sequentially as their open ends adjacent to the Tamayo Fracture Zone moved past the major source of terrigenous sediment transported by turbidity currents.

5) If conclusion 4 is correct, transcurrent faulting with sinistral relative displacement occurs along the Tamayo Fracture Zone southeast of its intersection with the axis of the East Pacific Rise, beyond the end of its transform portion.

\section{ACKNOWLEDGMENTS}

I thank Bob Sheridan, University of Delaware, and Claude Rangin, Université Pierre et Marie Curie, for their reviews of this paper.

\section{REFERENCES}

Gartner, S., 1977. Calcareous nannofossil biostratigraphy and revised zonation of the Pleistocene. Mar. Micropaleontol., 2:1-25.

Hays, J. D., and Shackleton, N. J., 1976. Globally synchronous extinction of the radiolarian Stylatractus universus. Geology, 4: 649-652.

Lewis, B.T.R., 1979. Periodicities in volcanism and longitudinal magma flow on the East Pacific Rise at $23^{\circ}$ N. Geophys. Res. Lett. (American Geophysical Union), 6(10):753-756. 